\title{
Influence of salinity on the dimethylsulphoniopropionate production from Prymnesium simplex
}

\author{
Dayala Vembilly Thariath, Dibu Divakaran and Sujatha Chenicherry ${ }^{*}$
}

\begin{abstract}
Dimethylsulphoniopropionate (DMSP) is a tertiary sulphonium compound which has received a considerable attention over recent years for acting as a principal intermediate in the production of dimethylsulphide, which is mostly noted as odour causing substance and it acts as a potential key player for climate regulation. The synthesis of DMSP is confined to some species of microalgae especially, prymnesiophytes and dinophytes and its concentration level varies with some environmental factors. In this context, this research work applies an experimental approach to assessing the production rate of DMSP under varying salinity (28, 30, 32 PSU) across distinctive growth phases. For this purpose, estuarine isolated microalgae, Prymnesium simplex (prymnesiophyceae) was selected as a model organism. The results showed that the growth rate response of $P$. simplex was significantly reduced at lower salinity (28 and 30 PSU) compared to higher salinity in this range (32 PSU). The concentration of DMSP and particulate fraction of DMSP was also elevated at higher salinity in the exponential phase of growth and lower at lower salinity. In contrast, the maximum production of dissolved DMSP was seen at lower salinity. Essentially research is to determine a maximum contribution of the regionally important prymnesiophyte family in the process of biogeochemical sulphur cycling.
\end{abstract}

Keywords: Dimethylsulphoniopropionate, Salinity, Osmolyte, Prymnesiophyceae, DMSPp, DMSPd

\section{Introduction}

Dimethylsulphide (DMS) is an important and abundant form of volatile sulphur gas emitted from the ocean surface. The major precursor of DMS is Dimethylsulphoniopropionate (DMSP), which is commonly known to be produced by microalgae [1]. Microalgae based DMSP production with its concurrent conversion to DMS has raised a novelty due to its significant influence on the regulation of climate pattern and is believed to help for controlling earth radiation balance [2]. The function of DMSP in microalgae varies based on its origin and associated with environmental conditions. However, the primary function in algal cells remains uncertain, but it has been suggested to act as an osmolyte [3, 4].

The synthesis of DMSP by microalgae cultures were examined by several investigators [5-7]. Challenger and Simpson [8] were the first pioneers to isolate DMSP from the marine algae, Polysiphonia fastigiata. An elaborate

\footnotetext{
* Correspondence: drchsujatha@yahoo.co.in

Department of Chemical Oceanography, Cochin University of Science and Technology, Kochi 682016, India
}

study was conducted by Keller et al. [1] from 123 clones of microalgal species representing 12 algal classes. The authors recorded a good correlation between microalgal taxa and DMSP content, where the prolific production of DMSP was noticed in prymnesiophytes and dinoflagellates. In later years, global pattern studies also considered prymnesiophytes as the dominant producers of DMSP in microalgal classes [9] and thus receiving a great deal of research attention.

Prymnesium simplex belonging to 'prymnesiophytes' and isolated from the Cochin Estuary (CE), South West coast of India was selected for a detailed investigation in this research endeavour. According to the morphological point of view, the size of prymnesiophytes was tiny in nature and the habitats of this species were widely found in estuarine and coastal zones. Besides, a few were also detected in the freshwater regions with cell densities $10^{6}-10^{7}$ cells $\mathrm{L}^{-1}[10,11]$. P. simplex is an inhabitant in $\mathrm{CE}$ and is noticed often in pre-monsoon season when the chloride content is high in estuarine waters.

(C) The Author(s). 2019 Open Access This article is distributed under the terms of the Creative Commons Attribution 4.0 International License (http://creativecommons.org/licenses/by/4.0/), which permits unrestricted use, distribution, and reproduction in any medium, provided you give appropriate credit to the original author(s) and the source, provide a link to the Creative Commons license, and indicate if changes were made. The Creative Commons Public Domain Dedication waiver (http://creativecommons.org/publicdomain/zero/1.0/) applies to the data made available in this article, unless otherwise stated. 
Several environmental factors have been shown to affect the ability to produce and accumulate DMSP in microalgae. Zhang et al. [12] recorded the impacts on certain environmental factors on the production of DMS and DMSPp in the laboratory cultures of microalgae. Among the factors, salinity in particular has extensively regulated the DMSP production and its accumulation [13-15]. Dickson and co-workers [16] were the first to report on the cellular DMSP concentrations, which tend to change with the varying amounts of chloride content in the green macroalgae, Ulva lactuca. Similarly, Beardall et al. [17] emphasise that the regional differences in salinity also have a profound influence on the production of DMSP. Hence, the current research work attributes mainly to improve the understanding of the production and release of DMSP by unialgal cultures of $P$. simplex, along with the detailed examination regarding the effect of salinity on growth and DMSP production in all the fractions.

\section{Materials and methods}

\section{Isolation of microalgae}

$P$. simplex was isolated from the middle of the CE, Kerala, India (lat. 09 $53.105^{\prime} \mathrm{N}$; long. 076 $16.043^{\prime} \mathrm{E}$ ). Surface water samples $(3 \mathrm{~L})$ were filtered through $20 \mu \mathrm{m}$ bolting silk. The filter containing microalgae can be removed by using spray bottle. Later the filtrate was allowed to settling for $5 \mathrm{~h}$ (a minimum time) to concentrate the sample. From this, $5 \mathrm{~mL}$ was taken and added to ten sets of $\mathrm{F} / 2$ media (Sigma-Aldrich) prepared from autoclaved seawater. Phytoplankton was isolated from the mixed culture by serial dilution and agar plating method [18].

\section{Identification of microalgae}

Molecular level identification was carried out using Genomic DNA extraction kit (Origin Diagnostics and Research, Kerala) and the PCR reactions were executed on a Thermocycler (T-100, Bio-Rad) using a program designed for the amplification of $18 \mathrm{~S}$ rRNA genes. Eukaryotic 18S rRNA genes were amplified with forward primer (5' -CTGGTTGATCCTGCCAGT-3') and reverse primer (5' - TAATGATCCTTCCGCAGGTTCACCT-3'). The PCR products were separated on $1.5 \%$ agarose gel.

\section{Culturing of microalgae}

Microalgae used in the experiments were grown in $250 \mathrm{~mL}$ batch cultures of F/2 medium [19], under 12:12 light:dark cycle in a temperature controlled room $\left(21 \pm 2{ }^{\circ} \mathrm{C}\right)$. Culture used for the experiment was unialgal and were maintained in triplicate. The sampling for the estimation and analysis was performed on alternate days and triplicate samples were used for all the estimations. To avoid the possibility of any existing diurnal rhythm in the cell division time, all the cultures were sampled at the same time on each day at 9 am over the course of entire experimental setup.

\section{Effect of salinity}

Further to extrapolate the effect of salinity on the DMSP content, $P$. simplex was cultivated at salinities of 28,30 and 32 PSU prepared by the addition of salt (sodium chloride) or sterile distilled water to a base F/2 medium, which was prepared from natural filtered and autoclaved seawater [20]. The cultures were inoculated with cells that had been pre-grown at the same salinity. A regular salinity check was performed with a hand refractometer (Erma) while keeping the other experimental conditions same as that of previous setup.

\section{Cell density}

Cell density was measured daily by placing an aliquot sample of well mixed culture suspension on a haemocytometer. The cells were counted in the five small squares in the centre block. The cell number in the culture was calculated by multiplying the number of cells counted, by the volume and the dilution [21].

\section{DMSP analysis}

DMSP is believed to be the only naturally occurring sulphonium compound that hydrolyzes into DMS and acrylic acid with aqueous alkali treatment at room temperature [22]. For determining DMSP, an aliquot of $5 \mathrm{~mL}$ unfiltered culture sample was directly added into the glass vial (Agilent Technologies) containing $0.5 \mathrm{~mL}$ of $10 \mathrm{M} \mathrm{NaOH}$ (to hydrolyze DMSP). Particulate DMSP (DMSPp) was measured using an aliquot of $5 \mathrm{~mL}$ culture was filtered using a glass fibre filters $(25 \mathrm{~mm}$, Whatman GF/F) in a filtration manifold (Pall) and the filters were placed in a glass vial containing $5 \mathrm{~mL}$ of sterile distilled water. Dissolved DMSP (DMSPd) was measured with the filtrates. Both filtrate and filters were added in separate $10 \mathrm{~mL}$ glass vials. After the addition of $\mathrm{NaOH}$, each vial was immediately sealed with aluminium crimp caps having Teflon-coated butyl rubber septa. The experimental samples were left to react in the dark at room temperature for a minimum of $12 \mathrm{~h}$, to continue the complete cleavage of DMSP to DMS. DMSP was measured indirectly as DMS through the gas chromatograph (GC) - headspace method [23].

The experiments were conducted in gas-tight vials, containing the liquid phase and a gas phase (air). After the DMSP degradation, DMS accumulate in the aqueous phase and is transferred by molecular diffusion into the gas phase of the vial (headspace). During the experimental course of time, sequential measurement of the DMS concentration in the headspace was used for calculating the production rate. The DMS was analysed in a GC system (Agilent Technologies, 7890A) equipped with a Flame 
Photometric Detector (FPD) and a Headspace Sampler (Agilent Technologies, 7697A). The temperature of the detector, injector and oven were 150,95 and $90{ }^{\circ} \mathrm{C}$, respectively. The flow of air, hydrogen and the carrier gas nitrogen, were 60,50 and $59.5 \mathrm{~mL} \mathrm{~min}^{-1}$ respectively. The retention time of DMS was $2.5 \mathrm{~min}$. Calibration curves were prepared by diluting a series of different stock concentrations of DMSP (Research Plus, USA) and further used as a working standard.

The ability of $P$. simplex to produce DMSP was first screened using GC-FPD headspace analysis. Further, for better selectivity and sensitivity, the DMSP content in $P$. simplex was re-analysed using GC-MS headspace analysis (Perkin Elmer). DMSP standard solution was first characterised to ensure accurate identification in the GC-MS analysis.

\section{Results and discussion \\ Molecular identification}

The study of phytoplankton and the precise identification of their species composition could provide useful information regarding their DMSP production. Rapid growth of molecular methods has been helpful to detect and identify at the species level of the microorganisms. To determine the primary phylogenetic affiliation, every sequence was compared with sequences offered in databases using Basic Local Alignment Search Tool (BLAST) from the National Centre for Biotechnology Information. The nucleotide sequences with the highest max scores were identified by the BLAST searches and were selected for use in the further analysis. From the obtained results of BLAST, the determined sequences corresponded to the known species and genus with a high sequence similarity. The isolated prymnesiophyte were affiliated with P. simplex (99\%) and has been deposited in GenBank under accession number MG774418.

\section{DMSP content in P. simplex}

Several kinds of studies have been reported for the production of DMSP from different classes of microalgae. However, according to the taxonomical point of view a significant DMSP production is confined to a few classes of microalgae mainly the prymnesiophytes followed by dinoflagellates, diatoms, chlorophytes and cyanophytes [1]. Further studies have reported that prymnesiophytes are the only group in which all the species tested are observed to produce DMSP $[8,14]$. During this study, out of the 19 species of microalgae isolated belonging to 7 different classes revealed the reality that prymnesiophytes were the prominent producers of DMSP. The report of DMSP production from $P$. simplex was investigated for the first time in the CE. Sophisticated methods were tested to prove the origin of species which could theoretically be useful in identifying DMSP rich phytoplankton taxa in situ. The detection of DMSP compound through GC-MS analysis, $P$. simplex was eluted at $1.71 \mathrm{~min}$. The details of total ion chromatogram (a), electron ionization mass fragmentation pattern (b) and NIST library data (c) are depicted in Fig. 1.

During the experimental period, DMSP content in $P$.

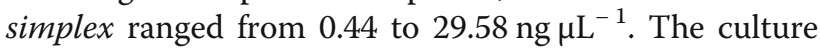
experiments with various species of prymnesiophyceae and their intracellular DMSP concentrations are listed in Table 1 . The results derived from laboratory experiments have shown that the values from the various studies are not similar to concentrations measured within the species of prymnesiophyceae [24-26]. This suggests that DMSP concentrations were highly species-specific and each species possess a remarkable ability to synthesise DMSP under varying environmental conditions. As per Van Alstyne and Puglisi [27], the variation in DMSP concentrations within prymnesiophyceae species can be genetically determined, environmentally induced, or affected by their combination.

\section{Effect of salinity on growth rate}

Growth rate experiments of $P$. simplex indicated that the cell density of the organism was different at each salinity concentrations. A long lag phase was observed in the culture growth at salinity 28 PSU (16 d) and relatively small lag phase was noticed in salinity 30 PSU (10 d) and 32 PSU (12 d), respectively. During the experimental course of time between day 18 and 23, the cell density at 32 PSU dropped from an initial value of $2.0 \times 10^{5}$ to $1.3 \times 10^{5}$ cells $\mathrm{mL}^{-1}$ and after day 23 , the cell density increased rapidly $\left(8.6 \times 10^{5}\right.$ cells $\left.\mathrm{mL}^{-1}\right)$. While the cultures at 28 and 30 PSU revealed a low cell density in the corresponding phase $\left(0.4\right.$ to $2.1 \times 10^{5}$ cells $\mathrm{mL}^{-1}$ and 0.5 to $2.1 \times 10^{5}$ cells $\mathrm{mL}^{-1}$ respectively) (Fig. 2 ). In the exponential phase, $P$. simplex grew rapidly (approximately six times) at salinity 32 PSU, in comparison to a slow and steady growth observed at lower salinities (28 and 30 PSU). Since rapid growth was noticed in the exponential phase at 32 PSU, it could be considered as the ideal phase of the organism for the active proliferation. The strain used for this laboratory study was isolated from the middle part of the $\mathrm{CE}$ during the summer season, wherein the aquatic system showed the salinity ranges from 19 to 30 PSU. It is well accepted that the middle part of the CE behaves as an extension of the Arabian Sea and shows high salinity during summer season [28]. The CE mostly experiences gradual and abrupt salinity changes. However, the salinity $<15$ PSU could not support the immense growth of $P$. simplex and simultaneously the absence of these species was also noticed in freshwater dominating areas.

Yang et al. [29] studied the variations in growth rate under varying salinities (20, 26 and 32 PSU) in Skeletonema 


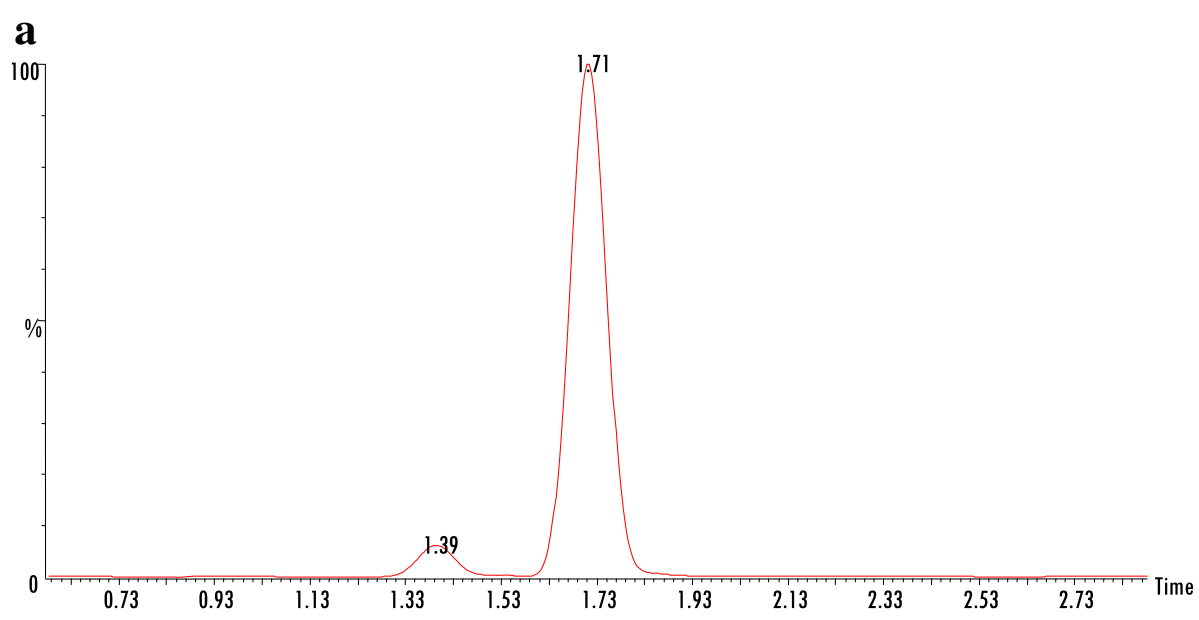

b

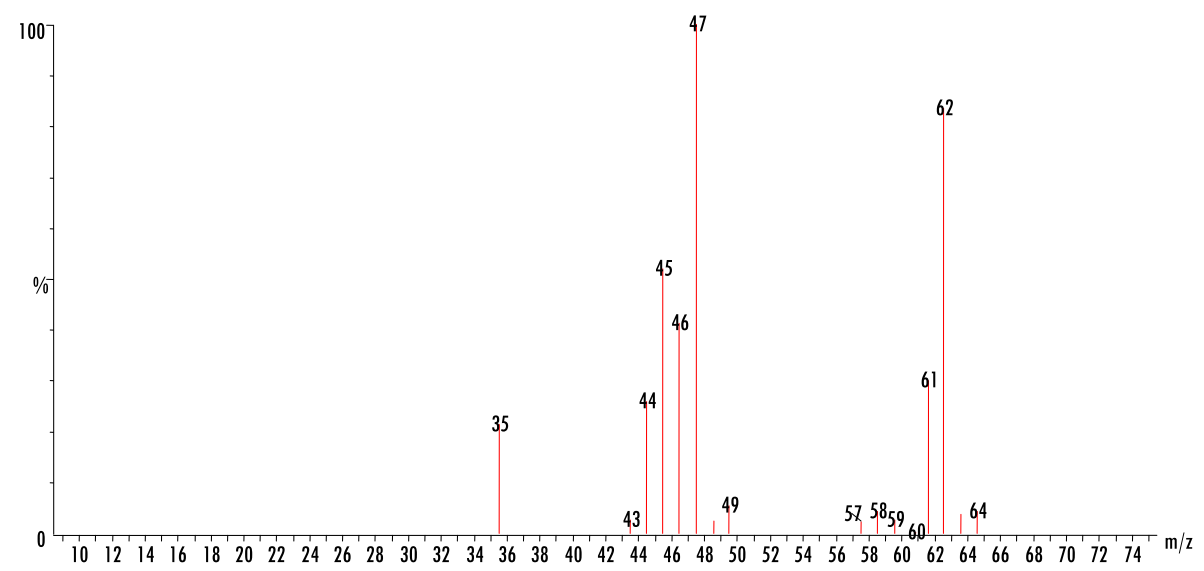

C

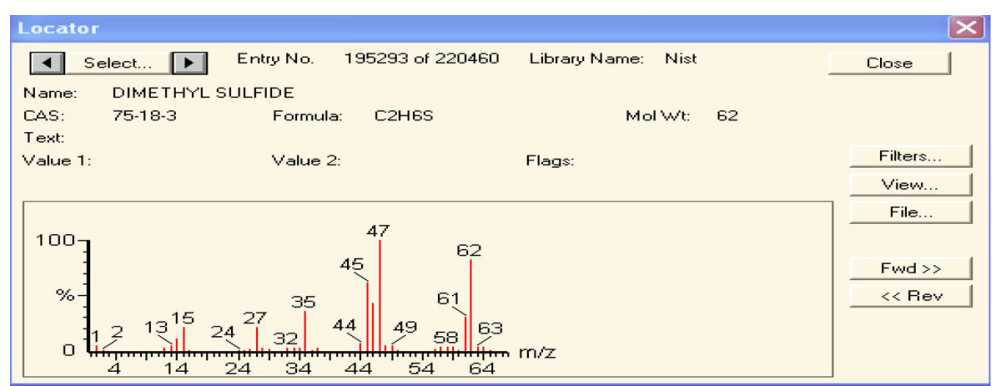

Fig. 1 (a) Total ion chromatogram, (b) Mass fragmentation pattern and (c) NIST library details of DMS identified from P. simplex

costatum. The authors concluded that the salinity exhibited a marked influence on the growth rate and a wide salinity tolerance. In another case study performed by Scholz and Liebezeit [30], three species of microalgae namely, Navicula phyllepta, Achnanthes delicatula and Nitzschia constricta, were isolated from the Solthorn tidal flat (lower Saxony, southern North Sea) and examined for their growth rates at different salinities $(0.5,10,20,30,40,50$ PSU). However, dissimilar growth rates have been observed among the species in which only $N$. phyllepta could alter the growth rate within the salinity range (30-50 PSU) whereas $A$. delicatula and $N$. constricta grew at salinities of $10-30$ and $0.2-10$ PSU, respectively. Generally, the difference in growth rate may be attributable to the size difference of the species and each species has its own salinity tolerance range for growth, while $P$. simplex, could have a physiological mechanism for coping with higher saline conditions. These studies of the selected species in suitable lab oriented conditions can be worked out in simulated field environment of the estuarine region for further research. 
Table 1 Intracellular concentration of DMSP in marine cultures of prymnesiophyceae

\begin{tabular}{|c|c|c|}
\hline Class: Prymnesiophyceae & DMSP concentration & References \\
\hline Prymnesium parvum & - & [4] \\
\hline Ruttnera spectabilis & - & [4] \\
\hline Emiliania huxleyi & $14 \mu \mathrm{mol}$ & {$[7]$} \\
\hline Phaeocystis sp. & $169 \mathrm{mM}$ & [22] \\
\hline Gephyrocapsa oceanica & $7 \mathrm{fmol}_{\text {cell }}{ }^{-1}$ & [24] \\
\hline Isochrysis galbana & $2.87 \mathrm{mM}$ & [24] \\
\hline Hymenomonas elongata & $48.44 \mathrm{mM}$ & [24] \\
\hline Emiliania huxleyi & $62.50 \mathrm{mM}$ & [24] \\
\hline Pleurochrysis carterae & $197.92 \mathrm{mM}$ & [24] \\
\hline Prymnesium parvum & $25.21 \mathrm{mM}$ & [24] \\
\hline Phaeocystis globosa & $43.40 \mathrm{mM}$ & [24] \\
\hline Isochrysis galbana & $129 \mathrm{mM}$ & {$[25]$} \\
\hline Hymenomonas carterae & $120 \mathrm{mM}$ & [26] \\
\hline Prymnesium simplex & $29.58 \mathrm{ng} \mathrm{\mu L}^{-1}$ & Present study \\
\hline
\end{tabular}

\section{Effect of salinity on DMSP}

The dynamics of the changes in DMSP accumulation in estuarine $P$. simplex in response to various saline treatments are illustrated in Fig. 3. There is no significant difference observed in DMSP production for cultures amended with salinity 28 and 30 PSU. During the initial 10-d, no significant elevation in DMSP was noted in all the culture samples which revealed that DMSP production is not a rapid shock regulator for $P$. simplex. However, after a span of 12-d, a noticeable increase was seen in the level of DMSP until the end of the exponential growth phase at salinity $28\left(15.0 \mathrm{ng} \mathrm{LL}^{-1}\right), 30(19.7 \mathrm{ng}$ $\mu \mathrm{L}^{-1}$ ) and 32 PSU (29.6 ng $\left.\mu \mathrm{L}^{-1}\right)$, respectively. The concentrations of DMSP increases with an elevation in external salt content as also noticed in many batch cultures of microalgae [31, 32]. DMSP was progressively accumulated in $P$. simplex in response to increase in salinity (32 PSU) of the media and the osmolyte action may therefore be linked to their use for coping with the salinity stress conditions. These unique characteristic features of this species make them able to adapt to elevated saline conditions which are prevailing in the CE aquatic niche implying a high probability for developing blooms and further production of more biogenic volatile sulphur gas. Thus, this species is not affected by a drastic variation in salinity caused by tidal exposure, evaporation, desiccation, precipitation and many other contributing processes taking place in both the adjoining brackish and marine waters.

As per the present examination, the exposure of $P$. simplex to increased salinity, showed no significant increase in DMSP content for a short-term duration (10-d) however, in long-term exposure (35-d) DMSP levels increased rapidly. Herewith, these observations revealed that DMSP production is not significant for the short-term acclimation due to the too slow rate of synthesis [33]. P. simplex showed marked variations in DMSP content under different salinities. At lower salinity, DMSP per cell density decreased and remained over a long period while at higher salinity DMSP per cell density increased and persisted for a short period of time. According to Edwards et al. [34], another possibility for DMSP increase was noticed in green macroalgae,

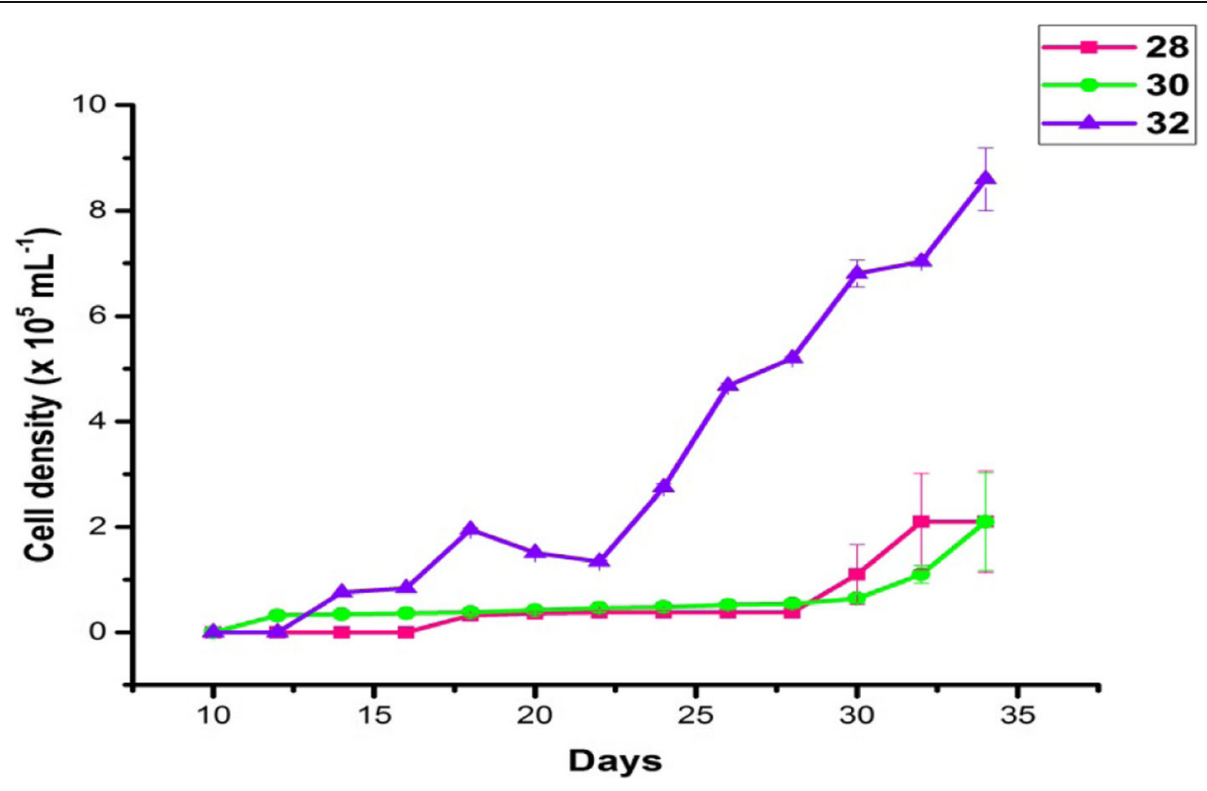

Fig. 2 Effect of salinity (PSU) on cell density in batch cultures of P. simplex 


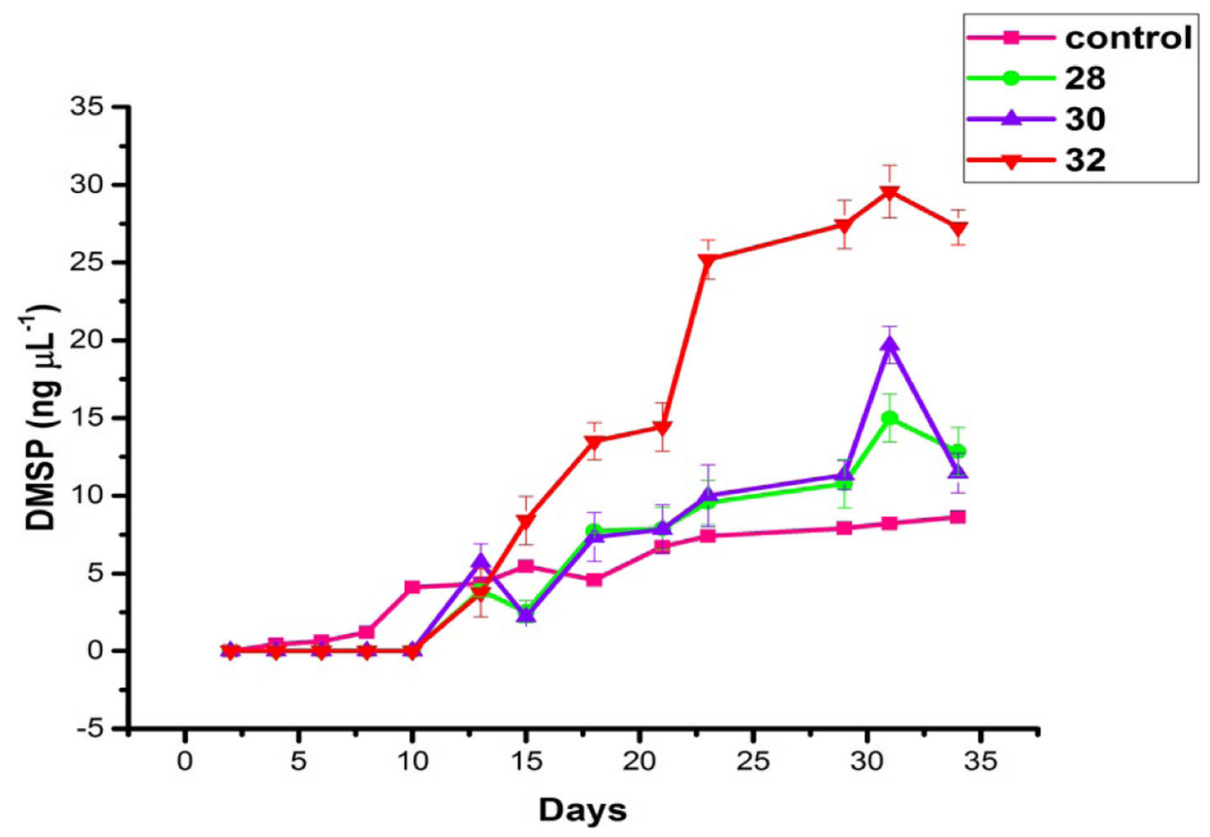

Fig. 3 Effect of salinity (PSU) on DMSP concentration in batch cultures of $P$. simplex

Enteromorpha intestinalis during exposure to varying saline conditions. In short-term incubation under hypersaline media (150 to $300 \%$ seawater, or 15 to $30 \mathrm{PSU}$ ) the proline and sucrose levels were merely increased. Whereas in the long-term exposure to high salinity, the sucrose levels declined and proline/DMSP levels highly amplified. This may suggest that the overlong exposure to hypersaline conditions led to changes in DMSP content. The outcomes are additionally reliable with the recommendation that DMSP acts as a compatible solute in prymnesium species.

\section{Effect of salinity on DMSPp and DMSPd}

Further, this study initiates to concentrate on the quantification of particulate and dissolved fractions of DMSP at different growth phases of $P$. simplex under varying saline conditions. It would also be particularly useful to perceive the uptake and excretion rate of DMSP by algae residing in an estuarine environment with fluctuating salinity. DMSPp also known as intracellular DMSP is defined as the fraction of DMSP retained on a filter (GF/F) including the whole microalgae. DMSPp is generally considered as the dominant component of the total DMSP pool [35]. The ranges of DMSPp concentration at salinity 28, 30 and 32 PSU were $3.1-23.7,2.6-14.7$ and $2.8-25.8 \mathrm{ng} \mu \mathrm{L}^{-1}$ respectively. The maximum concentration $\left(25.8 \mathrm{ng} \mu \mathrm{L}^{-1}\right)$ was noticed at higher salinity 32 PSU and the lowest concentration $\left(2.6 \mathrm{ng} \mu \mathrm{L}^{-1}\right)$ was observed at salinity $30 \mathrm{PSU}$ (Fig. 4a). When the salinity rises, the intracellular DMSP, an osmotically active compound, accumulates automatically in order to help algal cells for adjusting their osmotic potential. This suggests that $P$. simplex could contribute effectively to produce DMS from high saline situations within the estuarine field conditions. The higher concentration of DMS within the south-eastern Bering Sea was strongly related to the density of the prymnesiophyte, Phaeocystis poucheti [26]. During the period of study, a maximum concentration of DMSPp was recorded at the late stationary phase as a result of cell autolysis; remarked the reason by earlier reports [36]. Likewise, Matrai and Keller [37] investigated high DMSPp values in the last stages of a coccolithophore bloom. Different examinations also declared that higher DMS production in the senescent phase of blooms than during the initial phase [38].

DMSPd is considered as the extracellular DMSP and it is defined as the fraction of DMSP passing through the filter. The ranges of DMSPd at salinity 28,30 and 32 PSU were noticed $0.15-0.55,0.16-0.18$ and $0.10-0.16 \mathrm{ng}$ $\mu \mathrm{L}^{-1}$ respectively (Fig. $4 \mathrm{~b}$ ). The maximum concentration of DMSPd was analyzed at lower salinity 28 PSU ( 0.55 ng $\left.\mu \mathrm{L}^{-1}\right)$ and minimum was noticed at higher salinity 32 PSU $\left(0.10 \mathrm{ng} \mu \mathrm{L}^{-1}\right)$. In contrast to DMSPp, the higher concentrations of DMSPd were noticed in low saline condition. The release of DMSPd from the water column is assumed to be an important constituent of the dissolved organic carbon available to bacteria. According to Miller and Belas [39] the presence of DMSPd in the water column acts as a powerful signalling molecule. Therefore, the release of DMSPd under low salinity would be highly beneficial to bacteria, since at high saline conditions they showed comparatively low activity as was further supported by Van Bergeijk et al. [33]. 

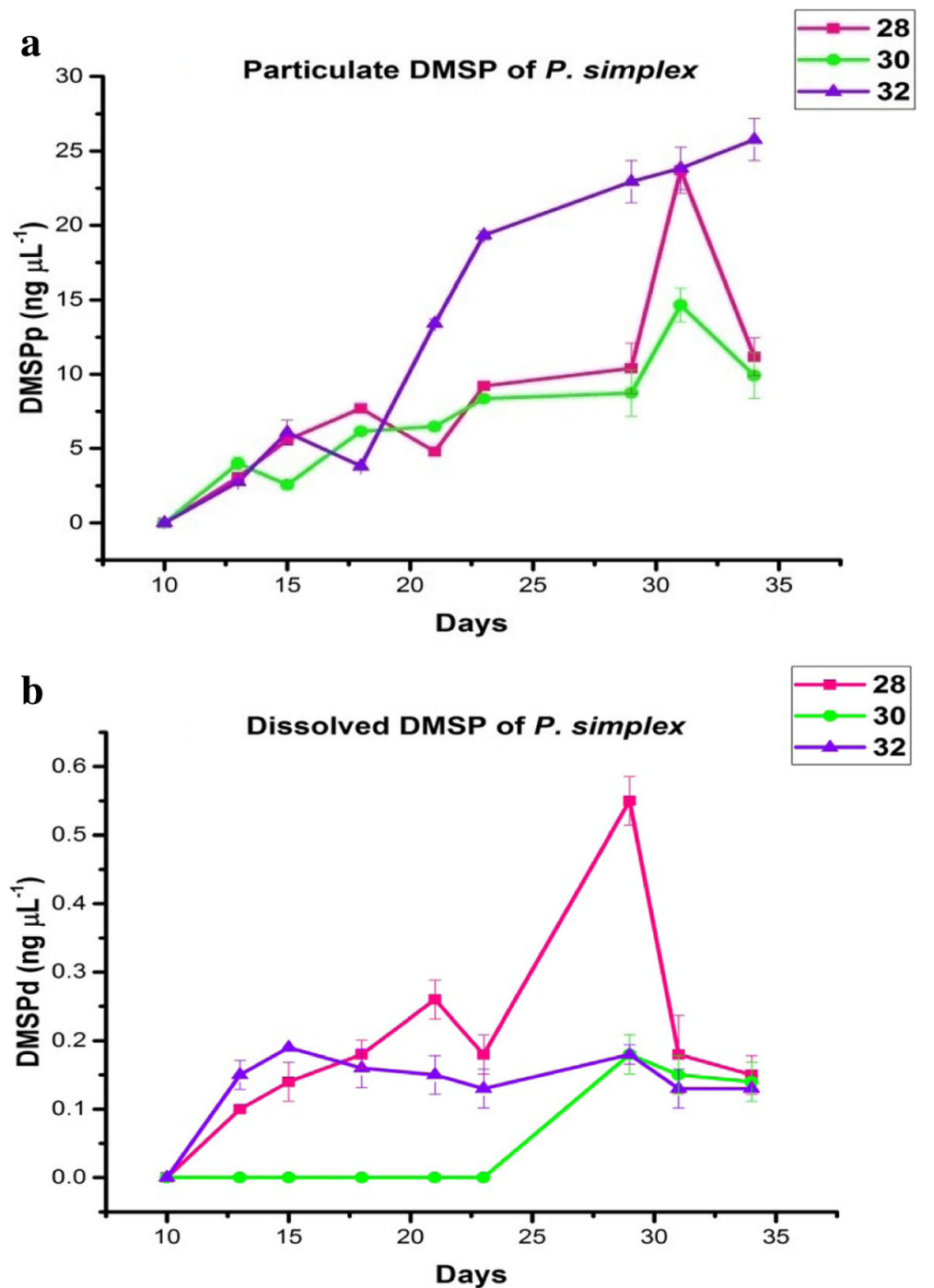

Fig. 4 (a) Effect of salinity (PSU) on DMSPp concentration in batch cultures of $P$. simplex and (b) effect of salinity (PSU) on DMSPd concentration in batch cultures of $P$. simplex

High productions of DMSPd were observed on the onset of the late stationary phase of culture. The earlier report suggests that the metabolism associated with active cell growth is noticed as rapid generation of DMSPd during this phase [5]. The lower DMSPd concentrations noticed in the present study was in all probability due to the production of DMSP lyase by this species [7].

\section{Conclusions}

The present generated information on growth related variations of DMSP and their fractions under varying saline conditions provides a primary insight into the production of DMSP by an ecologically important group of microalgae, $P$. simplex. The class of prymnesiophyceae (haptophyceae) was found to be the prolific producer of DMSP. P. simplex exhibited a marked influence on the growth rate under various saline conditions with a wide salinity tolerance. The experimental studies apparently perceived that significant rate of DMSP release per cell increased with the increasing salinities of the medium, which can be a consequence from intra-cellular DMSP up-regulation due to osmotic pressure. The essence of the results conveys that among the environmental factors, specifically salinity was noticed as a very important component that manages the planktonic production of atmospheric sulphur. Therefore, experimental evidence supports the role of DMSP as a compatible substance for the acclimatisation of $P$. simplex over varied salinity gradients and estimations of related physiological changes can enhance interpretation of environmental measurements. The outcome of this study can be used further for stepping into field oriented programme. 


\section{Acknowledgements}

The authors wish to express sincere thanks to the Director, Inter University Centre for Development of Marine Biotechnology (IUCDMB) and the Chemical Oceanography Department, CUSAT for providing laboratory facilities. This work was carried out by the utilisation of funds provided by the Department of Biotechnology (DBT), Government of India in the framework of the project entitled "Detection of DMSP (dimethylsulphoniopropionate) production in phytoplankton species using ddd gene encoding primers" by the grant (BT/PR3233/AAQ/03/566/2011) and greatly acknowledged. The authors express their heartfelt thanks for the scientific encouragement given by the Editor and the reviewers.

\section{Authors' contributions}

DVT carried out the isolation, culturing of the phytoplankton species along with their cell density and salinity studies and performed the statistical analysis. DD carried out the molecular genetic studies, participated in the sequence alignment and did the DMSP analysis using the GC-headspace method. DVT and SC participated in the design of the study and drafted the manuscript. All authors read and approved the final manuscript.

\section{Competing interests}

The authors declare that they have no competing interests.

\section{Publisher's Note}

Springer Nature remains neutral with regard to jurisdictional claims in published maps and institutional affiliations.

Received: 12 June 2018 Accepted: 29 January 2019 Published online: 02 May 2019

\section{References}

1. Keller MD, Bellows WK, Guillard RRL. Dimethyl sulfide production in marine phytoplankton. In: Saltzman ES, Cooper WJ, editors. Biogenic sulfur in the environment. Washington, DC: American Chemical Society; 1989. p. 67-182.

2. Charlson RJ, Lovelock JE, Andreae MO, Warren SG. Oceanic phytoplankton, atmospheric sulfur, cloud albedo and climate. Nature. 1987;326:655-61.

3. Vairavamurthy A, Andreae MO, Iverson RL. Biosynthesis of dimethylsulfide and dimethylpropiothetin by Hymenomonas carterae in relation to sulfur source and salinity variations. Limnol Oceanogr. 1985;30:59-70.

4. Dickson DMJ, Kirst GO. The role of $\beta$-dimethylsulphoniopropionate, glycine betaine and homarine in the osmoacclimation of Platymonas subcordiformis. Planta. 1986;167:536-43.

5. Li CX, Yang GP, Pan JF, Zhang HH. Experimental studies on dimethylsulfide (DMS) and dimethylsulfoniopropionate (DMSP) production by four marine microalgae. Acta Oceanol Sin. 2010;29:78-87.

6. van Rijssel M, Gieskes WWC. Temperature, light, and the dimethylsulfoniopropionate (DMSP) content of Emiliania huxleyi (Prymnesiophyceae). J Sea Res. 2002;48:17-27.

7. Stefels J, van Boekel WHM. Production of DMS from dissolved DMSP in axenic cultures of the marine phytoplankton species Phaeocystis sp. Mar Ecol Prog Ser. 1993;97:11-8.

8. Challenger F, Simpson MI. Studies on biological methylation. Part XII. A precursor of the dimethyl sulfide evolved by Polysiphonia fastigiata. Dimethyl-2-carboxyethylsulphonium hydroxide and its salts. J Chem Soc. 1948;3:1591-7.

9. Yoch DC. Dimethylsulfoniopropionate: its sources, role in the marine food web, and biological degradation to dimethylsulfide. Appl Environ Microb. 2002;68:5804-15.

10. Preisig HR. Phylum Haptophyta (Prymnesiophyta). In: John DM, Whitton BA, Brook AJ, editors. The freshwater algal Flora of the British Isles: an identification guide to freshwater and terrestrial algae. Cambridge: Cambridge University Press; 2002. p. 211-3.

11. Edvardsen B, Eikrem W, Throndsen J, Saez AG, Probert I, Medlin LK. Ribosomal DNA phylogenies and a morphological revision provide the basis for a revised taxonomy of the Prymnesiales (Haptophyta). Eur J Phycol. 2011;46:202-28

12. Zhang MP, Cui Z, Cui W, Wang F, Zhang HZ, Sheng P. Study on the dimethylsulfide and dimethylsulfoniopropionate in algae by laboratory batch cultures. Chin J Oceanol Limn. 1999;17:366-70.
13. Magalhaes C, Salgado P, Kiene RP, Bordalo AA. Influence of salinity on dimethyl sulfide and methanethiol formation in estuarine sediments and its side effect on nitrous oxide emissions. Biogeochemistry. 2012;110:75-86.

14. Stefels J, Steinke M, Turner S, Malin G, Belviso S. Environmental constraints on the production and removal of the climatically active gas dimethylsulphide (DMS) and implications for ecosystem modelling. Biogeochemistry. 2007;83:245-75.

15. Stefels J. Physiological aspects of the production and conversion of DMSP in marine algae and higher plants. J Sea Res. 2000;43:183-97.

16. Dickson DM, Wyn Jones RG, Davenport J. Steady state osmotic adaptation in Ulva lactuca. Planta. 1980;150:158-65.

17. Beardall J, Stojkovic S, Larsen S. Living in a high $\mathrm{CO}_{2}$ world: impacts of global climate change on marine phytoplankton. Plant Ecol Divers. 2009;2:191-205.

18. Helm MM, Bourne N. Hatchery culture of bivalves: a practical manual. Rome: Food and Agriculture Organization of the United Nations; 2004

19. Guillard RRL, Ryther JH. Studies of marine planktonic diatoms: I. Cyclotella nana Hustedt and Detonula confervacea (Cleve) gran. Can J Microbiol. 1962; 8:229-39.

20. Jean DS, Lee DJ. Effects of salinity on expression dewatering of waste activated sludge. J Colloid Interf Sci. 1999;215:443-5.

21. Andersen RA, editor. Algal culturing techniques. Burlington: Academic Press; 2005.

22. Dacey JWH, Blough NV. Hydroxide decomposition of dimethylsulfoniopropionate to form dimethylsulfide. Geophys Res Lett. 1987;14:1246-9.

23. Steinke M, Malin G, Turner SM, Liss PS. Determinations of dimethylsulphoniopropionate (DMSP) lyase activity using headspace analysis of dimethylsulphide (DMS). J Sea Res. 2000;43:233-44.

24. Hatton AD, Wilson ST. Particulate dimethylsulphoxide and dimethylsulphoniopropionate in phytoplankton cultures and Scottish coastal waters. Aquat Sci. 2007;69:330-40.

25. Spiese CE, Kieber DJ, Nomura CT, Kiene RP. Reduction of dimethylsulfoxide to dimethylsulfide by marine phytoplankton. Limnol Oceanogr. 2009;54:560-70.

26. Barnard WR, Andreae MO, Iverson RL. Dimethylsulfide and Phaeocystis poucheti in the southeastern Bering Sea. Cont Shelf Res. 1984;3:103-13.

27. Van Alstyne KL, Puglisi MP. DMSP in marine macroalgae and macroinvertebrates: distribution, function, and ecological impacts. Aquat Sci. 2007:69:394-402.

28. Vinita J, Revichandran C, Manoj NT. Suspended sediment dynamics in Cochin estuary, west coast, India. J Coast Conserv. 2017:21:233-44.

29. Yang GP, Zhang HH, Zhou LM, Yang J. Temporal and spatial variations of dimethylsulfide (DMS) and dimethylsulfoniopropionate (DMSP) in the East China Sea and the Yellow Sea. Cont Shelf Res. 2011;31:1325-35.

30. Scholz B, Liebezeit G. Compatible solutes in three marine intertidal microphytobenthic Wadden Sea diatoms exposed to different salinities. Eur J Phycol. 2012;47:393-407.

31. Kettles NL, Kopriva S, Malin G. Insights into the regulation of DMSP synthesis in the diatom Thalassiosira pseudonana through APR activity, proteomics and gene expression analyses on cells acclimating to changes in salinity, light and nitrogen. PLoS One. 2014;9:1-11.

32. Zhuang GC, Yang GP, YU JA, Gao YA. Production of DMS and DMSP in different physiological stages and salinity conditions in two marine algae. Chin J Oceanol Limn. 2011;29:369-77.

33. Van Bergeijk SA, Van der Zee C, Stal LJ. Uptake and excretion of dimethylsulphoniopropionate is driven by salinity changes in the marine benthic diatom Cylindrotheca closterium. Eur J Phycol. 2003;38:341-9.

34. Edwards DM, Reed RH, Stewart WDP. Osmoacclimation in Enteromorpha intestinalis: long-term effects of osmotic stress on organic solute accumulation. Mar Biol. 1988;98:467-76.

35. Dickson DMJ, Kirst GO. Osmotic adjustment in marine eukaryotic algae: the role of inorganic ions, quaternary ammonium, tertiary sulfonium and carbohydrate solutes II. Prasinophytes and haptophytes. New Phytol. 1987;106: 657-66.

36. Laroche D, Vezina AF, Levasseur M, Gosselin M, Stefels J, Keller MD, et al. DMSP synthesis and exudation in phytoplankton: a modeling approach. Mar Ecol Prog Ser. 1999;180:37-49.

37. Matrai PA, Keller MD. Dimethylsulfide in a large scale coccolithophore bloom in the Gulf of Maine. Cont Shelf Res. 1993;13:831-43.

38. Kwint RLJ, Kramer KJM. Dimethylsulphide production by plankton communities. Mar Ecol Prog Ser. 1995;121:227-37.

39. Miller TR, Belas R. Dimethylsulfoniopropionate metabolism by Pfiesteriaassociated Roseobacter spp. Appl Environ Microb. 2004;70:3383-91. 